\title{
Resisting Dehumanization
}

Books to Prisoners Seattle

B eing in prison is a fundamentally dehumanizing experience. Everything B in prison has been designed to strip the individuality, the motivation and the concept of the future from an individual. Under institutionalization, a person can be made to feel like little more than an extension of the building itself: meal times and ingredients, dress codes, and personal property are all dictated by the system. Prison is a self-contradictory regime of assimilation and isolation.

The current model of incarceration in the United States is retributive and expansively punitive (Alexander, 2010; Sweeney, 2010). The framework for incarceration presupposes deprivation as an impetus for rehabilitation; by controlling privileges, the system can - in theory-produce cooperative prisoners. Global austerity has made an easy target of prisoners, who are an uncharismatic demographic lacking lobbying power (Clark and MacCreaigh, 2006; Ings and Joslin, 2011). Private prisons, which win government contracts by promising lower costs and greater efficiency, are the culmination of this modern ideal of leanness (In the Public Interest, 2016). A company's focus on its saved costs is inherently in conflict with principles of nurturance and support for a group like people in prisons, who lack a financial stake in private prisons. In August 2016, the Office of the Inspector General at the U.S. Department of Justice determined that private prisons incurred more safety and security incidents than prisons run directly by the Bureau of Prisons. Private prisons also had a higher rate of misuse of solitary confinement and lacked proper medical oversight to ensure proper health care and treatment for inmates (Office of the Inspector General, 2016).

In the face of this systematic and intentional demoralization, books stand out as symbols of freedom. In a world where both information and bodies are tightly controlled, reading a book can be - in the words of incarcerated individuals themselves - an opportunity to feel less imprisoned (Betts, 2010; Rosenwald, 2011; Sweeney, 2010). The ideology of prison reading as liberation has a long history, from principles of prison bibliotherapy popularized in the 1960s and 1970s (Clements and McKee, 1968; Glasgow and Rosen, 1978) to Malcolm X's own transformation during incarceration as a young man. In his words, "I have often reflected upon the new vistas that reading opened to me. I knew right there in prison that reading had changed forever the course of my life. As I see it today, the ability to read awoke inside me some long dormant craving to be mentally alive" (X, 1964, p. 206). 
Access to books in prison fosters personal, mental and social health (Simunic et al., 2016). First, reading can be catalytic for stress relief. Reading, as a self-directed leisure activity, promotes psychological wellbeing (Nell, 1988). In a stressful environment such as a prison, books become tools for emotional self-management. The act of reading engages a reader's mind in a stimulating and pleasurable activity (Rafedzi and Abrizah, 2016). Research shows that sustained reading activates the brain's reward system (Kringelbach et al., 2008) and therefore is effective at relieving tension.

Readers report using books to reduce anxiety and to increase feelings of control over their surroundings by reducing distractions and unpleasant stimuli (Nell, 1988; Sweeney, 2010). Reading has been found to decrease readers' feelings of loneliness (Rane-Szostak, 1995). Reading also activates the areas of the brain responsible for building empathy towards others (Keen, 2006; Mar, 2011), which may encourage more positive social interactions. Voracious readers in prison even form stable communities - fundamental to buffering stress in prison (Nurse et al., 2003) - as people exchange books and book reviews (Sweeney, 2010). In sum, reading reduces stress and feelings of isolation.

Despite the many benefits of reading, people who are incarcerated often have a difficult time obtaining books. People who are incarcerated are not allowed to receive books that have been mailed directly by friends and families in jurisdictions where regulations exist whereby books may only be received from publishers or from organizations that specialize in mailing publications. Given the extraordinarily high rate of indigence among people who are incarcerated - and the costs of necessities such as phone calls, socks, and toothpaste - the majority of prisoners and their families are unable to afford to purchase books from publishers (DeVuono-Powell et al., 2015).

Prison libraries, another possible source of books, are often underfunded and undersupplied. State and federal prisons are required to provide access to a legal library (Bounds v. Smith, 1977). However, no similar mandate exists for non-legal reading materials. As a result, many prison libraries across the United States are severely underfunded for purchases of other reading materials, a situation that has been compounded by the recent recession (Lehmann, 2011). The sole source of funding for some libraries comes from a small portion of commissary and vending machine revenues (Sweeney, 2008). 
Most prison libraries are neither able to maintain a sufficiently varied inventory of books to satisfy all tastes nor able to keep an adequate stock of books to supply to every person (Shirley, 2003). San Quentin State Prison, for example, reduced its stock of library books by 75 percent over the course of fifteen years (Sweeney, 2008). Prison libraries often rely upon donations and interlibrary loan shipments to fill their shelves, which cannot guarantee an adequate or appropriate selection (Shirley, 2003; Sweeney, 2010). In most prisons, units must take turns browsing the stacks, which means that people may wait months between visits (Sweeney, 2010). Lockdowns, solitary confinement and being placed in a medical unit can further prevent an individual from visiting a library. Problematically, not every correctional facility even provides space for a library (Lehmann, 2011). In 2016, just 89 percent of incarcerated individuals had access to a library; individuals with access reported higher literacy than individuals without access, further demonstrating the benefits of consistent access to books (Rampey et al., 2016). The need for additional support for reading in prisons is clear.

Books to Prisoners began in 1973 alongside the Left Bank Books Collective, an anarchist book store in downtown Seattle, Washington. The founders of the Left Bank Books Collective recognized the deprivation inherent in the prison system and forged a program to support political prisoners through free, mailed reading materials. These materials often consisted of radical zines, legal briefings and other expressions of political solidarity. It soon became apparent that all incarcerated individuals - not just those incarcerated on the basis of their system of beliefs - needed as much support as possible from those on the outside. This support has not just been in the direct provision of books themselves, but in attempting to catalogue, publicize and fight ongoing issues of censorship in the form of books banned by individual prison mail rooms, each state's Department of Corrections, and the Federal Bureau of Prisons.

Thus, since its formation in 1973, the scope of Books to Prisoners has continued to expand. Since 1973, committed volunteers across the country have come together to form new groups of varying sizes and focuses. There are currently more than thirty groups in operation in this country. Some groups, such as LGBT Books to Prisoners in Madison, Wisconsin, serve specific demographics. Other groups, such as the Appalachian Prison Book Project in West Virginia, concentrate on certain states. 
Books to Prisoners in Seattle serves all eligible individuals in every state. In 2016, we even responded to requests from Washington, D.C. and Guam. We are, regretfully, unable to serve male prisoners in California, solely because of financial limitations. However, because we are not the only program of this nature in the United States, other groups such as the Prisoners Literature Project in San Francisco are able to respond to those individuals whom we are currently unable to support. Together, our groups are a coordinated network of politically active bookworms.

Books to Prisoners processed 15,000 requests for books in 2016 alone. Other groups around the country (including the Prisoners Literature Project; the Inside Books Project in Austin, Texas; and the Prison Book Program in Quincy, Massachusetts) are reporting similar volumes of requests. As the prison crisis continues, so does our work. To those who are incarcerated, we say: do not forget that you will always be part of a larger community. We are a collective who want to support your needs and your future. We are here for you.

In solidarity, Books to Prisoners in Seattle

\section{REFERENCES}

Alexander, Michelle (2010) The New Jim Crow: Mass Incarceration in the Age of Colorblindness, New York City: The New Press.

Betts, Dwayne (2010) A Question of Freedom: A Memoir of Learning, Survival, and Coming of Age in a Prison, New York: Avery.

Bounds v. Smith, 430 U.S. 817 (1977).

Clark, Sheila and Erica MacCreaigh (2006) Library Services to the Incarcerated, Westport (CT): Libraries Unlimited.

Clements, Carl B. and John M. McKee (1968) "Programmed Instruction for Institutionalized Offenders: Contingency Management and Performance Contrasts", Psychological Reports, 22(3): 957-964.

DeVuono-Powell, Saneta, Chris Schweidler, Alicia Walters and Azadeh Zohrabi (2015) Who Pays? The True Cost of Incarceration on Families, Oakland: Ella Baker Center.

Glasgow, Russell E. and Gerald M. Rosen (1978) "Behavioral Bibliotherapy: A Review of Self-help Behavior Therapy Manuals", Psychological Bulletin, 85: 1-23.

In the Public Interest (2016) Cutting Corners in America's Criminal Justice System. Retrieved from <https://www.inthepublicinterest.org/wp-content/uploads/ITPI CuttingCorners_Corrections_April2016.pdf>

Ings, Catherine and Jennifer Joslin (2011) "Correctional Services of Canada Prison Libraries from 1980 to 2010", Library Trends, 59(3): 386-408.

Keen, Susan (2006) “A Theory of Narrative Empathy”, Narrative, 14(3): 207-236. 
Kringelbach, Morten L., Peter Vuust and John Geake (2008) “The Pleasure of Reading”, Interdisciplinary Science Reviews, 33(4): 321-335.

Lehmann, Vibeke (2011) "Challenges and Accomplishments in U.S. Prison Libraries", Library Trends, 59(3): 490-508.

Mar, Raymond A. (2011) "The Neural Bases of Social Cognition and Story Comprehension", Annual Review of Psychology, 62: 103-134.

Nell, Victor (1988) "The Psychology of Reading for Pleasure: Needs and Gratifications", Reading Research Quarterly, 23(1): 6-50.

Nurse, Jo, Paul Woodcock and Jim Ormsby (2003) "Influence of Environmental Factors on Mental Health within Prisons: Focus Group Study", British Medical Journal, 327(7413): 480-483.

Office of the Inspector General (2016) Review of the Federal Bureau of Prisons' Monitoring of Contract Prisons, Washington (DC): Evaluation and Inspections Division. Retrieved from $<$ https://oig.justice.gov/reports/2016/e1606.pdf $>$.

Rafedzi, E.R.K. and A. Abrizah (2016) "Information Needs of Male Juvenile Delinquents: The Needs to be Met in a Prison Setting", Information Development, 32(3): 592-607.

Rampey, Bobby D., Shelley Keiper, Leyla Mohadjer, Tom Krenzke, Jianzhu Li, Nina Thornton, and Jacquie Hogan (2016) Highlights from the U.S. PIAAC Survey of Incarcerated Adults: Their Skills, Work Experience, Education, and Training: Program for the International Assessment of Adult Competencies - 2014, Washington (DC): National Center for Education Statistics. Retrieved from $<\mathrm{http}$ ://nces.ed.gov/ pubsearch>.

Rane-Szostak, Donna and Kaye A. Herth (1995) "Pleasure Reading, Other Activities, and Loneliness in Later Life", Journal of Adolescent \& Adult Literacy, 39(2): 100108.

Rosenwald, Michael S. (2011) "A believer in books behind bars", The Washington Post - March 26.

Shirley, Glennor L. (2003) "Correctional Libraries, Library Standards, and Diversity", Journal of Correctional Education, 54(2): 70-74.

Simunic, Zrinka, Sanjica F., Tanackovic and Boris Badurina (2016) "Library Services for Incarcerated Persons: A Survey of Recent Trends and Challenges in Prison Libraries in Croatia", Journal of Librarianship and Information Science, 48(1): 72-89.

Sweeney, Megan (2008) "Reading and Reckoning in a Women's Prison", Texas Studies in Literature and Language, 50(3): 304-328.

Sweeney, Megan (2010) Reading is My Window: Books and the Art of Reading in Women's Prisons, Chapel Hill: The University of North Carolina Press.

X, Malcolm and Alex Haley (1965) The Autobiography of Malcolm X, New York: Grove Press. 